\title{
COMPENDIUM
}

\section{INTERACTIVE PREPROCESSORS FOR SAP IV, NASTRAN, AND ADINA IN THE TEACHING ENVIRONMENT}

\author{
Movses J. KaLDJian \\ Departments of Naval Architecture and Marine Engineering, and Civil Engineering, University of \\ Michigan, Ann Arbor, MI 48109-2145, U.S.A.
}

(Received 28 July 1988)

\begin{abstract}
Input data preparation in general is the main chore in finite element analysis. Interactive preprocessors can provide the engineer with an easy guide and efficient method of communicating the mathematical model to the computer. Essentially the same modeling information has to be supplied to all finite element programs. A preprocessor can be made to accommodate internally the input data variations peculiar to each finite element program. Learning to model on one finite element program may then be adequate to allow the engineer to prepare data for other finite element programs through a well planned preprocessor. Three such preprocessors, PREMSAP, PNASTRAN and PADINA, have been developed in Fortran for SAP IV, NASTRAN and ADINA respectively. Typical interactive conversations of these, and their output, are presented here for a 3D bracket, and may be compared. These preprocessors, coupled with a graphics package, proved very useful in training students in finite element analysis in class study, as well as with engineers and researchers in their work.
\end{abstract}

\section{PREPROCESSORS}

Input data preparation in general is the main chore in finitc clement modeling and analysis, and may account for $80 \%$ or more of the total analysis cost. Interactive preprocessors can provide the engineer with an easy guide and efficient method of communicating his mathematical model to the computer by avoiding unnecessary mistakes and reducing time consuming verifications.

Essentially the same modeling information has to be supplied to all finite element programs. Preprocessors can be made to accommodate internally the input data variations peculiar to each finite element program. Learning to model on one finite element program may then be adequate to allow the engineer to prepare data for other finite element programs through a well planned preprocessor.

Input data may be prepared with an interactive preprocessor on micro computers, which are readily available and inexpensive, and then this data may be verified graphically for accuracy with a graphics package before running it on micro or mainframe computers to obtain the finite element results.

Three such preprocessors, PREMSAP [1-3], PNASTRAN $[3,4]$ and PADINA, have been written in Fortran for SAP IV [5], NASTRAN [6] and ADINA [7] respectively for linear analysis. Typical interactive conversations of these programs and their output are shown below for a 3D bracket problem, and may be compared.

No attempt is made here to describe SAP IV, NASTRAN or ADINA's program element components nor their input data statements. For this the reader is referred to the respective manuals whose references appear at the end of this text. It is of course recommended, though not essential for simple problems, to read the manuals and get acquainted with finite element techniques prior to running the appropriate preprocessor on the computer.

The preprocessors prompt the engineer in very similar language. They all have nodal and element mesh generation, as well as 2D and 3D options with or without rotation constraints. The user is prompted each step of the way and needs to enter the requested information format free.

After the user has defined his problem with proper sketches and dimensions, from a terminal he calls on the preprocessor he wants to use. This can be accessed on the Michigan Terminal System (MTS) by typing the appropriate command shown in the Appendix.

The name of the file to store the input data for the finite element program is created internally, and the data are saved within it according to the appropriate format of the particular finite element program being used.

Corrections to the input data file may be made by rerunning the preprocessors or by editing this file directly. Nonlinear parameters and/or bulk data may be added to the data file as desired.

The process of requesting information by the computer and the user's response to it continues until the last bit of information necessary to complete the input data for MSAP is accomplished.

These processors, when coupled with a graphics package [1,2], have been shown to be very useful in training students in finite element analysis in class 


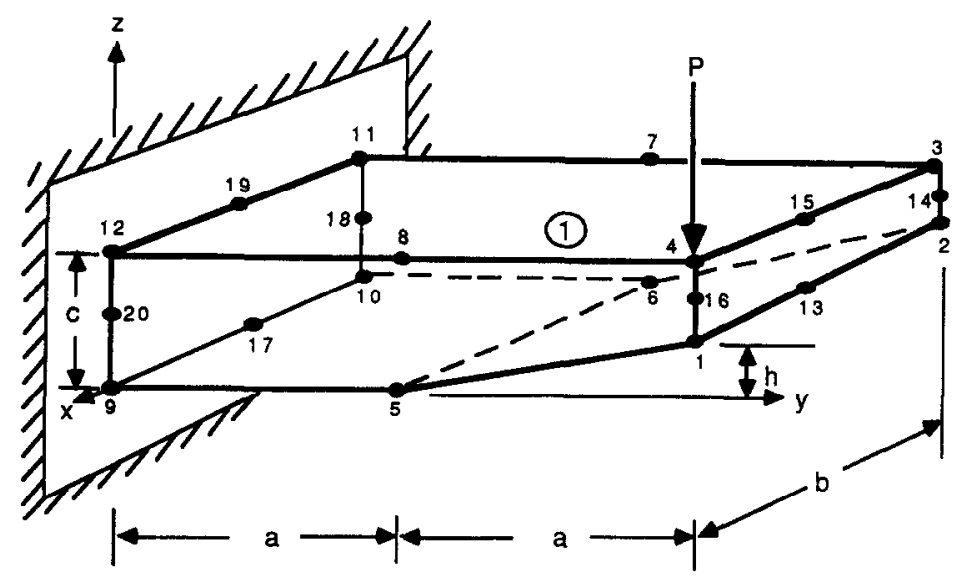

Fig. 1. Aluminum bracket.

study, as well as with engineers and researchers in their work. The computer knowledge required of them is thus reduced to a minimum.

It is easy to extend these preprocessors to accommodate other finite element programs. Use of these preprocessors by students, researchers and industry has proved to be very satisfying.

\section{ILLUSTRATED EXAMPLE}

Input data for finite element analysis of a $2 \times 3 \times 6$ in. aluminum bracket, shown in Fig. 1 , is to be prepared for: $Y . M .=10,000 \mathrm{ksi}(68.95 \mathrm{GPa})$, $v=0.3, \quad P=8 \mathrm{kip}(35.584 \mathrm{kN}), \quad$ and $a=3 \mathrm{in}$. (76.2 $\mathrm{mm}), b=3$ in. $(76.2 \mathrm{~mm}), c=2$ in. $(50.8 \mathrm{~mm})$, and $h=1 \mathrm{in}$. $(25.4 \mathrm{~mm})$.
Using the preprocessors discussed above, appropriate input data for
(a) MSAP (SAP IV),
(b) NASTRAN and
(c) ADINA

have been prepared interactively, and are presented below for comparison.

\section{COMPUTER CONVERSATION}

The interactive computer conversation of the preprocessors PREMSAP, PNASTRAN, and PADINA to obtain input data for the bracket shown in Fig. 1 follows next, along with SAP IV, NASTRAN and ADINA analysis results of the same.

\section{\#RUN CENA.PREMSAR}

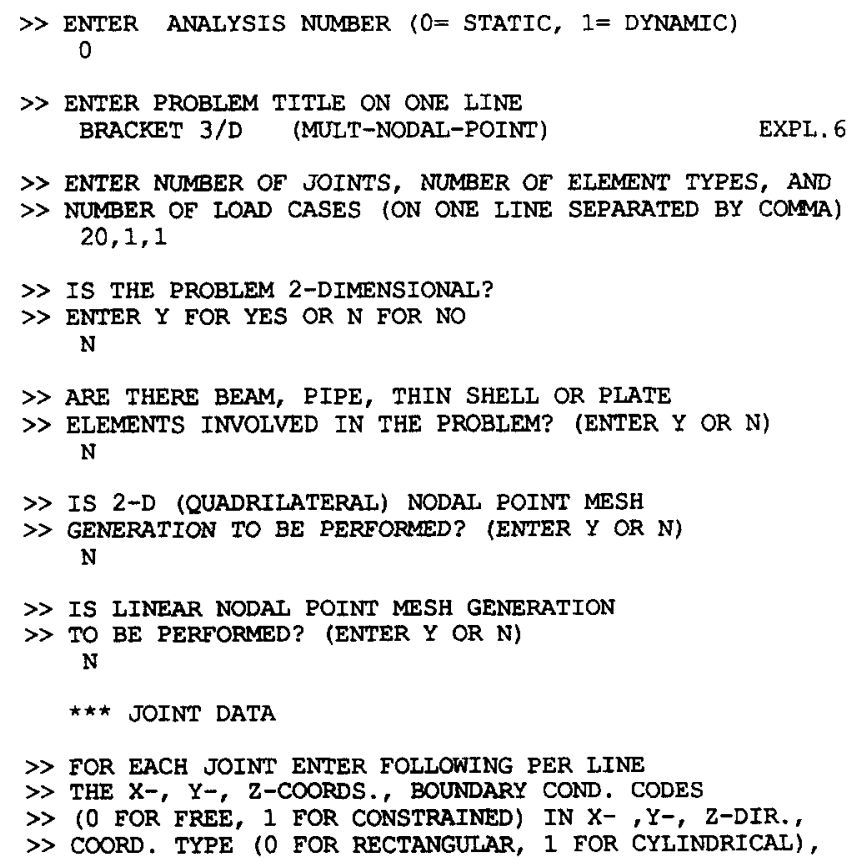




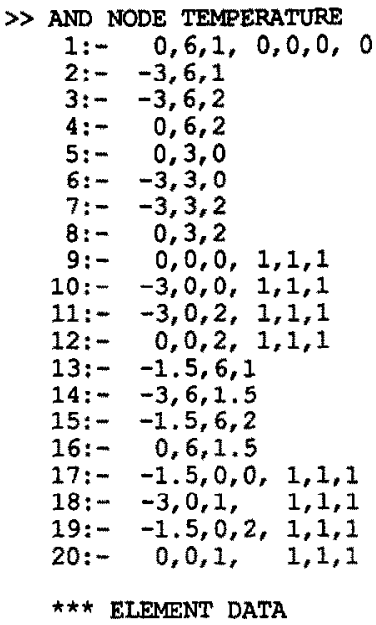

$\gg$ ENTER ELEMENT TYPE NUMBER

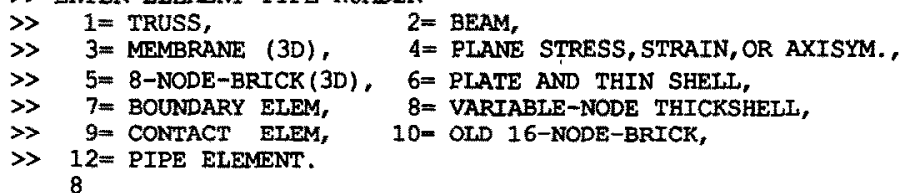

* ENTER the follóning 6 items

... NUMBER OF ELEMENTS, NUMBER OF DIFFERENT MATERTALS,

. . MAX NUMBER OF TEMP. POINTS FOR ANY MATERIAL,

. . NUMBER OF DIFFERENI DISTRIBUTED IOAD SETS,

... MAX NUMBER OF NODES TO DESCRIBE AN ELLMENT, AND

...NUMBER OF SETS OF DATA REQUESTING STRESS OUTPUT

... AT VARIOUS locations.

... (ON ONE IINE SEPARATED BY COMMA)

$? 1,1,1,0,20,1$

...FOR EACH MATL ENTER NUMBER OF DIFFERENT TEMPERATURES

...AT WHICH MATL PRORERTIES ARE SPECIFIED,

...AND WEIGHT \& MASS DENSITIES 1: 1

$>$ FOR EACH DIF. TEMP FOR IHIS MATERIAL ENTER

$>$ TEMPERATURE, MODULUS OF EIASTICITY, POISSONS RATIO, $>$ AND THERMAI EXPANSION COEFFICIENT.

1) $0,10000, .3$

... SPECIFY UP TO SEVEN STRESS LOCATIONS

...FOR EACH OUTPUT SET (FROM 1 TO 27)

1: $3,4,7,8,10,12,14$

... ARE THERE GRAVITY, THERMAI, OR DISTRIBUTED IOADS

.. APPLIED? (ENTER Y OR N)

$? \mathrm{~N}$

$\gg$ IS LINEAR ELEEMENT MESH GENERATION

$\gg$ TO BE PERFORMED? (ENTER Y OR N)

? $\mathrm{N}$

* ENTER the FOLIONTNG 7 TTEMS pER eLEMENT

. . NUMBER OF NODES DESCRIBING THE ELEMENT DISPIACEMENTS,

... NUMBER OF NODES TO DESCRIBE EIEMENT GEOMETRY,

... MATERTAL ID NUMBER.

. . STRESS OUTPUT SET NUMBER,

. . . STRESS FREE TEMPERATURE.

...STIFFNESS SAME AS PRECEDING ELEMENT? $(0=\mathrm{NO}, 1=\mathrm{YFS})$,

- AND PRESSURE SET NUMBER

1: $20,20,1,1,0,0,0$

*IIST DESCRIBING NODE NUMBERS

$? 3,11,12,4,2,10,9,1,7,19,8,15,6,17,5,13,14,18,20,16$

***CONCENTRATED IOAD DATA

\) ENTER NUMBER OF JOINTS WITH CONCENTRATED LOADS

$\gg$ FOR EACH LOADED JOINT ENTER FOLLOHING PER LINE

$\gg$ JOINT NO. (IN TNCREASING SEQ.), AND LOADS IN $X-, Y-, Z-D I R$.

$4,0,0,-8$ 
$\gg$ THE PROGRAM IS READY TO STORE THE DATA IN YOUR OWN FILE

$\gg$ ACCORDING TO THE INPUT FORMAT OF MSAP

$\gg$ ENTER YOUR OWN FILE NAME (8 CHARACTERS OR LESS) EXPL. 6M

$\gg$ YOU ARE NOW READY TO OBTAIN YOUR RESULTS BY TYPING:

$\gg$ SLIST EXPL. 6

LISTING

$\gg$ \$RUN CENA:MSAP SCARDS=EXPL. 6 SPRINT=-RESULT < ANALYSIS

$\gg$ \$RUN CENA:MSAPLOT

$<$ DISPIAY

\#I.TST EXPT.GM (DATA FOR MSAF)

BRACKET 3/D MULT. NODAL POINTS

EXPL. 6

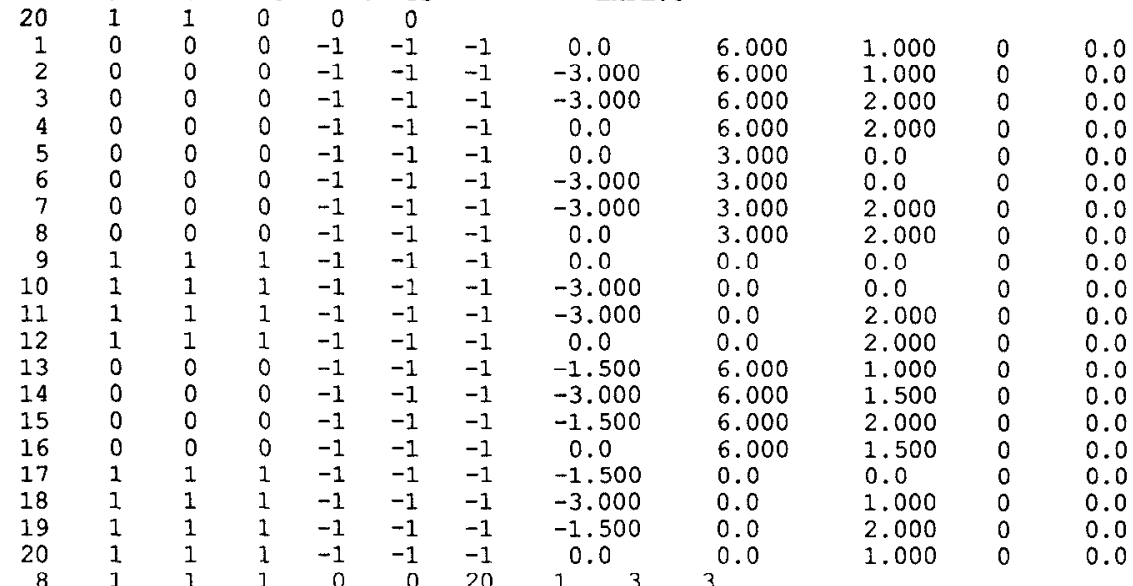

$\begin{array}{lllllll}1 & 1 & 0.0 & 0.0 & & \\ 0.0 & 1.000 \mathrm{E}+04 & 1.000 \mathrm{E}+04 & 1.000 \mathrm{E}+04 & 3.000 \mathrm{E}-01 & 3.000 \mathrm{E}-01 & 3.000 \mathrm{E}-01 \\ 3.846 \mathrm{E}+03 & 3.846 \mathrm{E}+03 & 3.846 \mathrm{E}+03 & 0.0 & 0.0 & 0.0\end{array}$
3.846
0.0
0.0

$\begin{array}{rrrr}3 & 4 & 7 & \\ & 0.0 & & 0.0 \\ & 0.0 & & 0.0 \\ & 0.0 & & 0.0 \\ & 0.0 & & 0.0 \\ & 0.0 & & 0.0 \\ 1 & 20 & 20 & 1 \\ 4 & 3 & 11 & 12 \\ 16 & 14 & 18 & 20 \\ 4 & 1 & 0.0 & \end{array}$

$\begin{array}{ll}8 & 10 \\ 0 & \\ 0 & \\ 0 & \\ 0 & \\ 0 & \\ 1 & \\ 12 & \\ 20 & \\ & 0.0\end{array}$
$0.0 \quad 0.0$
$0.0 \quad 0.0$
$0.0 \quad 0.0$
0.0

$-8.000 \mathrm{E}+00 \quad 0.0$

$\begin{array}{rr}0 & 0 \\ 7 & 19\end{array}$

$\begin{array}{lllll}0 & 0 & 0 & 0 & 0\end{array}$

0.0

0.0

0.0

0.0

EXAMPLE 6

BRACKET 3-D MULT> NODAL POINTS

NODE DISPIACEMENTS/ROTATIONS

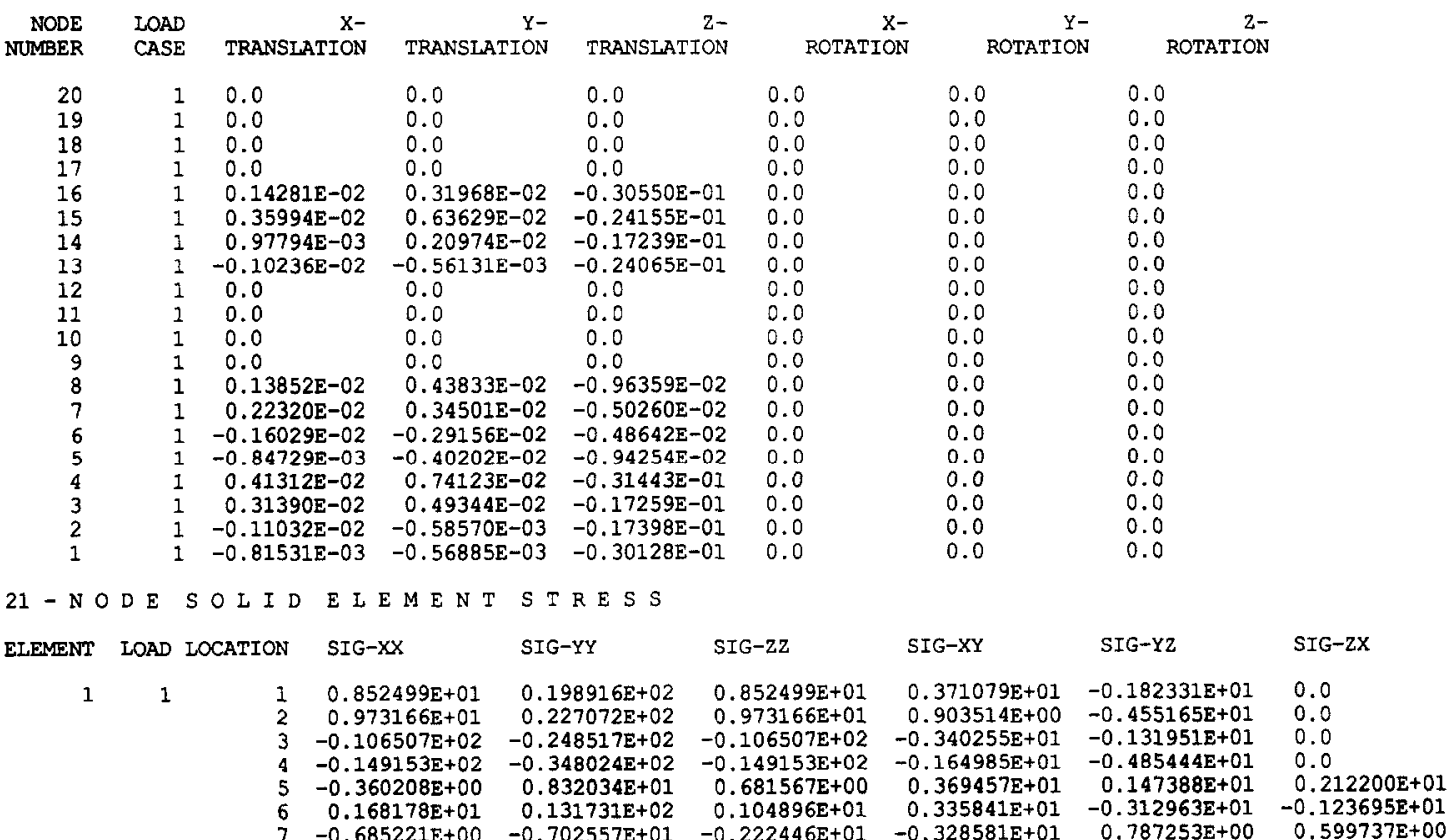




\section{\#BON CTRIA:PMASTRAN}

<* ENTER FILE NAME TO STORE NASTRAN DATA

? EXPL. 6N

$\star \star \star$ EXECUTIVE CONTROI DECK:

*ENTER PROBLEM ID NAME IN TWO WORDS

(EACH 8 CHARACTER OR LESS) SEPARATED BY A COMMA.

?ID = THICK, SHELL

$\star * \star$ CASE CONTROL DECK:

*ENTER A DESCRIPTIVE TITLE

?TITLE= BRACKET $3 / D$ (MULT-NODAL-POINT) NASTRAN

<*> IS THE PROBLEM BEING ANALYSED 2-DIMENSIONAL?

< > NOTE: RIAATES WITH BENDING ARE CONSIDERED 3-D.

$\langle\star\rangle$ (ENTER Y FOR YES, OR N FOR NO)

? $\mathrm{N}$

<> ARE THERE BENDING MOMENT RESISTING MEMBERS

«> (SUCH AS BEAM, PLATE, ETC.)? ENTER Y OR N.

? $\mathrm{N}$

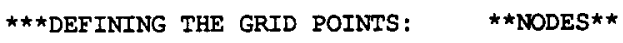

< > IS AUTO GRID POINT (NODE) MESH GENERATION

$<\star>$ TO BE PERFORMED? ENTER $Y$ OR $N$

? $\mathrm{N}$

*FOR EVERY GRID POINT (JOINT) ENTER PER LINE,

GRID ID, AND THE $X, Y$, AND $Z$ COORDIATES.

\TO CORRECT AN ERROR: RE-ENTER "GRID ID", AND THE COORD/S.

\TO DEIETE A LINE: ENTER "-GRID ID", AND ZEROS

FOR THE COORDINATES (ANY NUMBER WILL DO).

*TERMINATE THIS SEQUENCE BY TYPING: \$ENDFILE (OR CTRL-C)

? $1,0,6,1$

$2,-3,6,1$

$3,-3,6,2$

$40,6,2$

$4,0,6,2$

$5, \quad 0,3,0$

$6,-3,3,0$

$7,-3,3,2$

$8,0,3,2$

9, $0,0,0$

? $10,-3,0,0$

? $11,-3,0,2$

? $12,0,0,2$

? $13,-1.5,6,1$

? $14,-3,6,1,5$

? $15,-1.5,6,2$

? $16,0,6,1.5$

$17,-1.5,0,0$

? $18,-3,0,1$

? $19,-1.5,0,2$

? $20,0,0,1$

? 1

$\star \star \star$ GRID POINT (JOINT) CONSTRAINTS:

\#ENTER GRID ID AND UP TO THREE DIGIT CONSTRAINT

(1 FOR X-DIR, 2 FOR Y-DIR, AND 3 FOR Z-DIR - WITHOUT

BLANKS OR COMMAS IN BETWEEN - I.E. 123 ).

*TERMINATE THIS SEQUENCE BY TYPING: SENDFILE (OR CTRI-C)

? 9,123

? 10,123

? 11,123

? 12,123

? 17,123

? 18,123

19,123

? 20,123

? 1

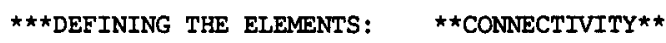

*ENTER THE ELEMENT TYPE (NUMBER) :

1 = BEAM . . . . . CBAR

2 = PLANE STRESS $\cdot \cdot \cdot$. CQUAD4

3 = PIANE STRESS: : CQUAD8

4 = PLATE. . . . . COUAD4

$5=$ SOLID. . . . . . CHEXA20
5

« > IS AUTO ELEMENT (CONNECTIVITY) MESH GENERATION 
$<\star>$ TO BE PERFORMED FOR THTS ELEMENT TYPE? ENTER Y OR N $? \mathrm{~N}$

***EIEMENT DATA FOR: SOLID ELEMENT **CHEXA**

*FOR EACH PROPERTY OF THIS ELEMENT TYPE,

ENTER PROPERTY ID, AND MATERTAI ID.

\TO CORFECT AN ERROR: RE-ENTER "PROPER'Y ID",

AND MATERIAI ID.

>TO DELETE A LINE: ENTER "-PROPERTY ID", AND A ZERO (OR ANY OTHER NUMBER) FOR MATERIAL ID.

*TERMINATE THIS SEQUENCE BY TYPING: \$ENDFILE (OR CTRL-C)

$$
? 21,11
$$

* ENTER THE YOUNG'S MODULUS, AND pOISSON'S RATIO

FOR MATERTAL ID:

$? 11=10000,0.3$

*FOR EACH CHEXA ELEMENT,

ENTER ELEMENT ID, AND ITS 20 GRID ID'S

(CONNECTIVITY POINTS - USE THE RIGHT HAND RULE)

>TO CORRECT AN ERROR; RE-ENTER "ELEMENT ID", AND THE 20 GRID ID'S.

>TO DELETE A LINE: ENTER "-ELEMENT ID", AND ZEROS (OR ANY OTHER NUMBER) FOR THE 20 GRID ID'S.

*TERMINATE THIS SEQUENCE BY TYRING: \$ENDFIIE (OR CTRL-C) $? 1,4,3,11,12,1,2,10,9,15,7,19,8,16,14,18,20,13,6,17,5$ $?$

<* ARE THEHE OTHER ELEMENT TYQES

$<\star>$ YET TO BE ENTERED IN THIS PROBLEM? ( $Y$ OR N) $? \mathrm{~N}$

*** LOAD SUBCASES

*ENTER The NUMBER of LOAD SETS TO be APPLIED.

$? 1$

*ENTER TITLE fOR sUbcase 1

? POINT FORCE

$\star \star \star$ CONCENTRATED FORCES ON GRID POINTS:

*FOR EACH FORCE IOAD ENTER PER LINE

THE GRTD ID WAERE THE IOAD IS APPLIED, AND ITS $X, Y, A N D Z$

COMPONENIS (I,E, GID, FX, FY, EZ) .

>>TO CORRECT AN ERROR: RE-ENIER "GRID ID", AND THE FURCE COMPONENTS.

\TO DELETE A LINE: ENTER "-GRID ID", AND ZEROS

(OR ANY OTHER NUMBER) FOR ITS FORCE COMPONENTS.

*TERMINATE THIS SEQUENCE BY TYPING: \$ENDFILE (OR CTRL-C)

FOR SUBCASE ( 1 )

SUBTTTLE: POTNT FORCE

$? 4,0,0,-8$

?

\section{\#LIST EXPT, GN}

(DATA FOR NASTRAN)

ID THICK, SHEIT

TIME 1

SOL 24

SDIAG 14

CEND

TITLE $=$ BRACKET $3 / 0$ (MULT-NODAL-POTNT) NASTRAN

ECHO=SORTED

DISPLACEMENI $=A L I$

EIFORCE=ALL,

SPCFORCES $=$ ALI

SUBCASE 1

$L O A D=61$

SUBTITLE= POINT FORCE

OUTPUT (PLOT)

PLOTTER NASTRAN

SET 53 INCLUDE AIT

AXES $2, X, Y$

VIEW $0,0,0$

FIND

PLOT LABEI BOTH

PLOT STATIC DEFORMATION 0 SET 53

BEGIN BULK

PARAM AUTOSPC YES

GRDSET

GRDSE

$\frac{1}{2}$

GRID

GRID

1
2
3

0.0
-3.00
-3.00

6.00

6.00

1.00

$6.00 \quad 2.00$ 


\begin{tabular}{|c|c|c|c|c|c|c|c|c|}
\hline GRID & 4 & & 0.0 & 6.00 & 2.00 & & & \\
\hline GRID & 5 & & 0.0 & 3.00 & 0.0 & & & \\
\hline GRID & $\epsilon$ & & -3.00 & 3.00 & 0.0 & & & \\
\hline GRID & 7 & & -3.00 & 3.00 & 2.00 & & & \\
\hline GRID & 8 & & 0.0 & 3.00 & 2.00 & & & \\
\hline GRID & $s$ & & 0.0 & 0.0 & 0.0 & & 123456 & \\
\hline GRID & 10 & & -3.00 & 0.0 & 0.0 & & 123456 & \\
\hline GRID & 11 & & -3.00 & 0.0 & 2.00 & & 123456 & \\
\hline GRID & 12 & & 0.0 & 0.0 & 2.00 & & 123456 & \\
\hline GRID & 13 & & -1.50 & 6.00 & 1.00 & & & \\
\hline GRID & 14 & & -3.00 & 6.00 & 1.50 & & & \\
\hline GRID & 15 & & -1.50 & 6.00 & 2.00 & & & \\
\hline GRID & 16 & & 0.0 & 6.00 & 1.50 & & & \\
\hline GRID & 17 & & -1.50 & 0.0 & 0.0 & & 123456 & \\
\hline GRID & 18 & & -3.00 & 0.0 & 1.00 & & 123456 & \\
\hline GRID & 15 & & -1.50 & 0.0 & 2.00 & & 123456 & \\
\hline GRID & 20 & & 0.0 & 0.0 & 1.00 & & 123456 & \\
\hline CHEXA & 1 & 21 & 4 & 3 & 11 & 12 & 1 & \\
\hline+21001 & & & & & & & & \\
\hline+21001 & 10 & 9 & 15 & 7 & 19 & 8 & 16 & $+\mathrm{B} 1001$ \\
\hline$+\mathrm{B} 1001$ & 18 & 20 & 13 & 6 & 17 & 5 & & \\
\hline PSOLID & 21 & 11 & & & & & & \\
\hline MATI & $11]$ & +04 & & .300 & & & & \\
\hline FORCE & 61 & 4 & 0 & 1.0 & 0.0 & 0.0 & -8.00 & \\
\hline ENDDATA & & & & & & & & \\
\hline
\end{tabular}

\section{I S P I A C E M N T VECTOR}

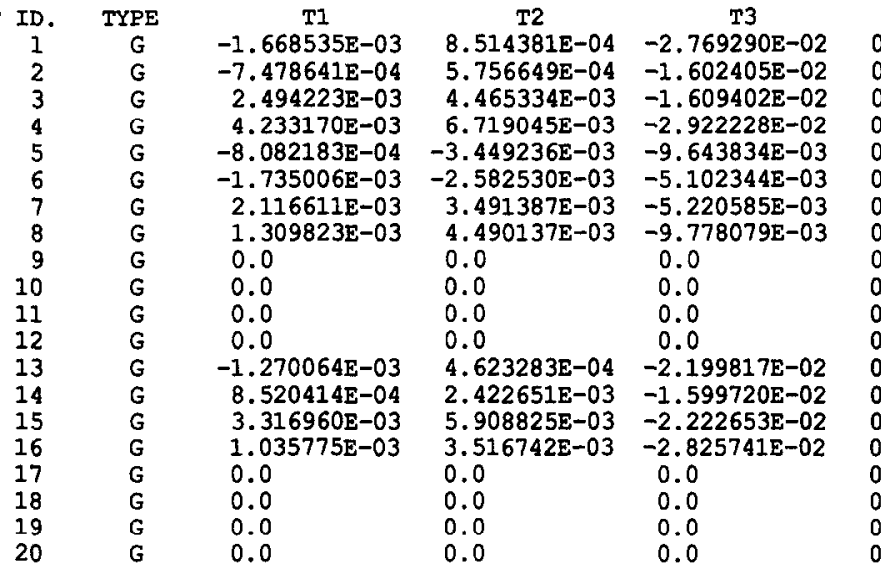

$\begin{array}{lll}R 1 & R 2 & R 3 \\ 0.0 & 0.0 & 0.0 \\ 0.0 & 0.0 & 0.0 \\ 0.0 & 0.0 & 0.0 \\ 0.0 & 0.0 & 0.0 \\ 0.0 & 0.0 & 0.0 \\ 0.0 & 0.0 & 0.0 \\ 0.0 & 0.0 & 0.0 \\ 0.0 & 0.0 & 0.0 \\ 0.0 & 0.0 & 0.0 \\ 0.0 & 0.0 & 0.0 \\ 0.0 & 0.0 & 0.0 \\ 0.0 & 0.0 & 0.0 \\ 0.0 & 0.0 & 0.0 \\ 0.0 & 0.0 & 0.0 \\ 0.0 & 0.0 & 0.0 \\ 0.0 & 0.0 & 0.0 \\ 0.0 & 0.0 & 0.0 \\ 0.0 & 0.0 & 0.0 \\ 0.0 & 0.0 & 0.0 \\ 0.0 & 0.0 & 0.0\end{array}$

FORCES OF SINGIE-POINT CONSTRAINT

POINT ID, TYPE

$\begin{array}{rr}\text { ID. } & \text { TYP } \\ 10 & \\ 11 & \\ 12 & \\ 17 & \\ 18 & G \\ 19 & \\ 20 & G\end{array}$

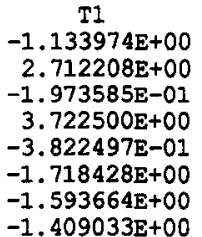

$\mathrm{T} 2$
$8.058518 \mathrm{E}+00$
$6.898411 \mathrm{E}+00$

2

$6.898411 \mathrm{E}+00$
$-1.231961 \mathrm{E}+00$

$-1.550229 \mathrm{E}+00$

$1.515567 \mathrm{E}+01$

$-5.691678 \mathrm{E}+00$

$-1.510521 \mathrm{E}+01$

$-6.533518 \mathrm{E}+00$

$\begin{array}{cr}T 3 & R 1 \\ 1.060886 \mathrm{E}+01 & 0.0 \\ 9.637033 \mathrm{E}+00 & 0.0 \\ 8.229043 \mathrm{E}+00 & 0.0 \\ 1.077604 \mathrm{E}+01 & 0.0 \\ 5.657729 \mathrm{E}+00 & 0.0 \\ -2.608670 \mathrm{E}+01 & 0.0 \\ 1.029323 \mathrm{E}+01 & 0.0 \\ -2.111522 \mathrm{E}+01 & 0.0\end{array}$

R2
0.0

0.0

0.0

0.0

0.0

0.0

0.0

STRESSES IN HEXAHEDRON SOLID ELEMENTS (HEXA)

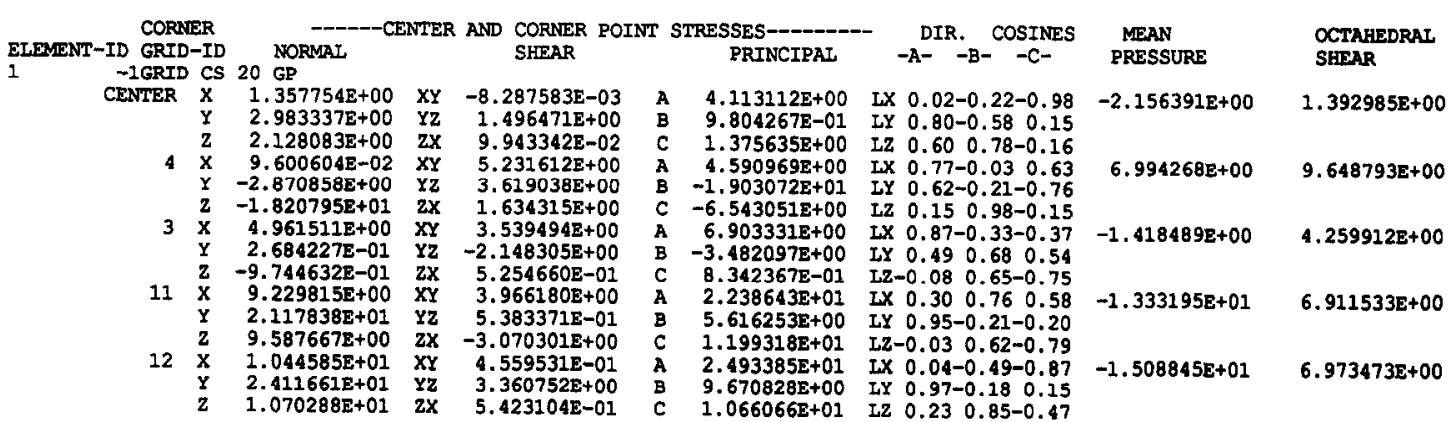




\section{\#RUN CENA:PADINA}

*3 ENTER FILE NAME TO STORE ADINA DATA (7 CHARACTERS OR LESS) ? EXPT, 68

* $>$ ENTER PROBLEM TITLE ON ONE LINE.

? $3 / D$ SOLID

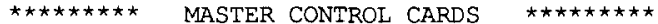

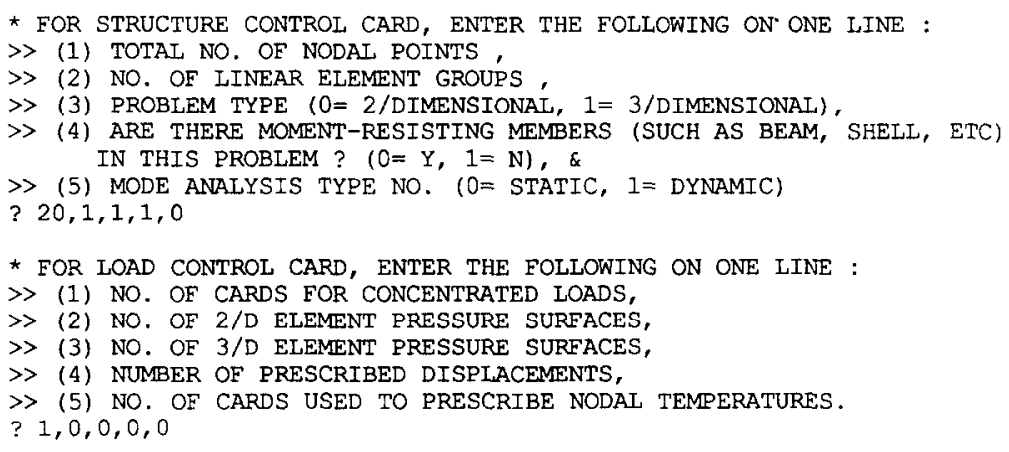

* FOR STRUCTURE CONTROL CARD, ENTER THE FOLLOWING ON ONE LINE :

$\gg$ (1) TOTAL NO. OF NODAL POINTS,

$\gg$ (2) NO. OF LINEAR ELEMENT GROUPS

$\gg$ (3) PROBT.EM TYPE ( $0=2$ /DTMENSIONAT., $1=3 /$ DTMFNSIONAI.).

$\gg$ (4) ARE THERE MOMENT-RESISTING MEMBERS (SUCH AS BEAM, SHELI, ETC)

IN THIS PROBLEM ? $(\mathrm{O}=\mathrm{Y}, 1=\mathrm{N})$

$\gg$ (5) MODE ANALYSIS TYPE NO. $(0=$ STATIC, $1=$ DYNAMIC $)$

$20,1,1,1,0$

* FOR LOAD CONTROL CARD, ENTER THE FOLLOWING ON ONE LINE :

$\gg$ (1) NO. OF CARDS FOR CONCENTRATED LOADS,

$\gg$ (2) NO. OF 2/D ELEMENT PRESSURE SURFACES,

$\gg$ (3) NO. OF $3 / D$ ELEMENT PRESSURE SURFACES,

$\gg$ (4) NUMBER OF PRESCRIBED DISPLACEMENTS,

$\gg$ (5) NO. OF CARDS USED TO PRESCRIBE NODAL TEMPERATURES

$? 1,0,0,0,0$

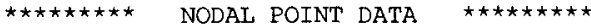

* For EACH NODAL POINT, ENTER the FOLLOWING PER LINE :

$\gg$ (1) NODE NO.

$\gg(2-4) X-, Y-$, AND Z-COORD.,

$\gg(5-7) X-, Y-$, AND 2-TRANS. BOUNDARY CODE, $(0=$ FREE, $1=$ CONSTRAINED )

$\gg$ (8) NODE' NO.' INCREMENT FOR MESH GENERATION.

** TO CORRECT AN ERROR: RE-ENTER THE ENTIRE LINE

** TO DELETE A LINE: ENTER "-NODE NO.", AND ZEROS.

** TERMINATE THIS SEQUENCE BY TYPING \$ENDFILE (OR CNTR-C).

? $1,0,6,1,0,0,0,0$

$? 2,-3,6,1,0,0,0,0$

? $3,-3,6,2,0,0,0,0$

$4,0,6,2,0,0,0,0$

? $5,0,3,0,0,0,0,0$

$6,-3,3,0,0,0,0,0$

$7,-3,3,2,0,0,0,0$

$8,0,3,2,0,0,0,0$

$9,0,0,0,1,1,1,0$

$10,-3,0,0,1,1,1,0$

$11,-3,0,2,1,1,1,0$

$12,0,0,2,1,1,1,0$

? $13,-1.5,6,1,0,0,0,0$

? $14,-3,6,1.5,0,0,0,0$

? $15,-1,5,6,2,0,0,0,0$

? $16,0,6,1.5,0,0,0,0$

? $17,-1.5,0,0,1,1,1,0$

? $18,-3,0,1,1,1,1,0$

? $19,-1.5,0,2,1,1,1,0$

? $20,0,0,1,1,1,1,0$

$?$

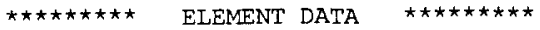

* ENTER ELEMENT TYPE NO. FOR LINEAR ANAIYSIS :

$\gg 1=$ TRUSS, $2=2 / \mathrm{D}$ PLANE $/$ SOLID

$\Rightarrow 3=3 / D$ SOLID, $\quad 4=$ BEAM,

$\gg 7=$ SHEIL.

? 3

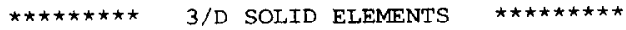

* FOR 3/D SOLID ELEMENTS, ENTER THE FOLLOWING ON ONE LINE : $\gg$ (1) NO. OF ELEMENTS,

$\gg$ (2) MAX. NO. OF NODES USED TO DESCRIBE ANY ONE ELEMENT

$>$ (3) NO. OF STRESS OUTPUT TABLES (AT INTEG.PTS. $=$ ZERO), 
> (4) NO. OF DIFFERENT SETS OF MATERIAL PROPERTIES.

? $1,1,20,1,1$

* FOR EACH MATERIAL PROPERTY, gNTER THE FOLIOWING PER LINE :

$\gg$ (1) MATERIAL PROPERTY SET NO., (2) MASS DENSITY

$>$ (3) YOUNG'S MODULUS,

(2) MASS DENSTTY,

* IF THE LINE INPUT IS ERRONEOUS, ENTER AGATN.

* TERMTNATE THIS SEQUENCE BY TYPING \$ENDEILE (OR CNTR-C).

? $1,010000.3$

* STRESS OUTPUT location POINTS ON ELEMENT:

> ENTER TABLE NO. \& 8 NODE POINTS FOR DESIRED STRESSES.

$\gg$ NOTE: SEE ADINA FIG. XIII.7 FOR LOCATION NUMBERS.

* IF THE LINE INPUT IS ERRONEOUS, ENTER AGAIN,

* TERMINATE THIS SEQUENCE BY TYPING \$ENDEILE (OR CNTR-C).

? 1.347810121416

?

* FOR BACH 3/D SOLID ELEMENT, ENTER THE FOLLONING PER LINE :

$\gg$ (1) ELEMENT NO.

(2) NO. OE NODES,

$\gg$ (3) STRESS OUTPUT TABLE NO.

$\gg$ (4) MATERIAI, PROPERTY SET NO.

$\gg(5-25)$ GLORAL NODE NO. OF ELEMENT NODAL POINT 1 TO 21 ,

$\gg$ (26) NODE GENERATION INCREMENT.

** TO CORRECT AN ERROR: RE-ENTER THE ENTIRE LINE.

* * TO DELETE A LINE: ENTER "-ELEMENT NO.", AND ZEROS.

** TERMINATE THIS SEQUENCE BY TYPING SENDFILE (OR CNIR-C).

? $1,2011,431112,12109,157198,136175,161418200,0$

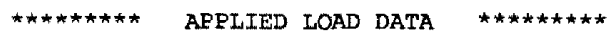

* FOR CONCENTRATED LOADS, ENTER THE FOLLOWING 5 ITEMS PER LINE:

$\gg$ (1) LOADING CARD NO.

$\gg$ (2) NODE NO. TO WHICH THIS LOAD IS APPLIED,

$\gg$ (3) DOF NO. FOR THIS LOAD COMPONENT,

$\gg \quad(1,2,3=X-, Y-, Z$-TRANS., $4,5,6=X-, Y-, Z$-ROT.

$\gg$ (4) FUNCTION MUTTIPLIER,

$\gg$ (5) NODE NO. INCREMENT FOR GENERATION.

* IF THE LINE INPUT IS ERRONEOUS, ENTER AGAIN.

* * TERMINATE THIS SEQUENCE BY TYPING \$ENDFILE (OR CNTR-C).

$? 1,4,3,-8,0$

\#Execution terminated

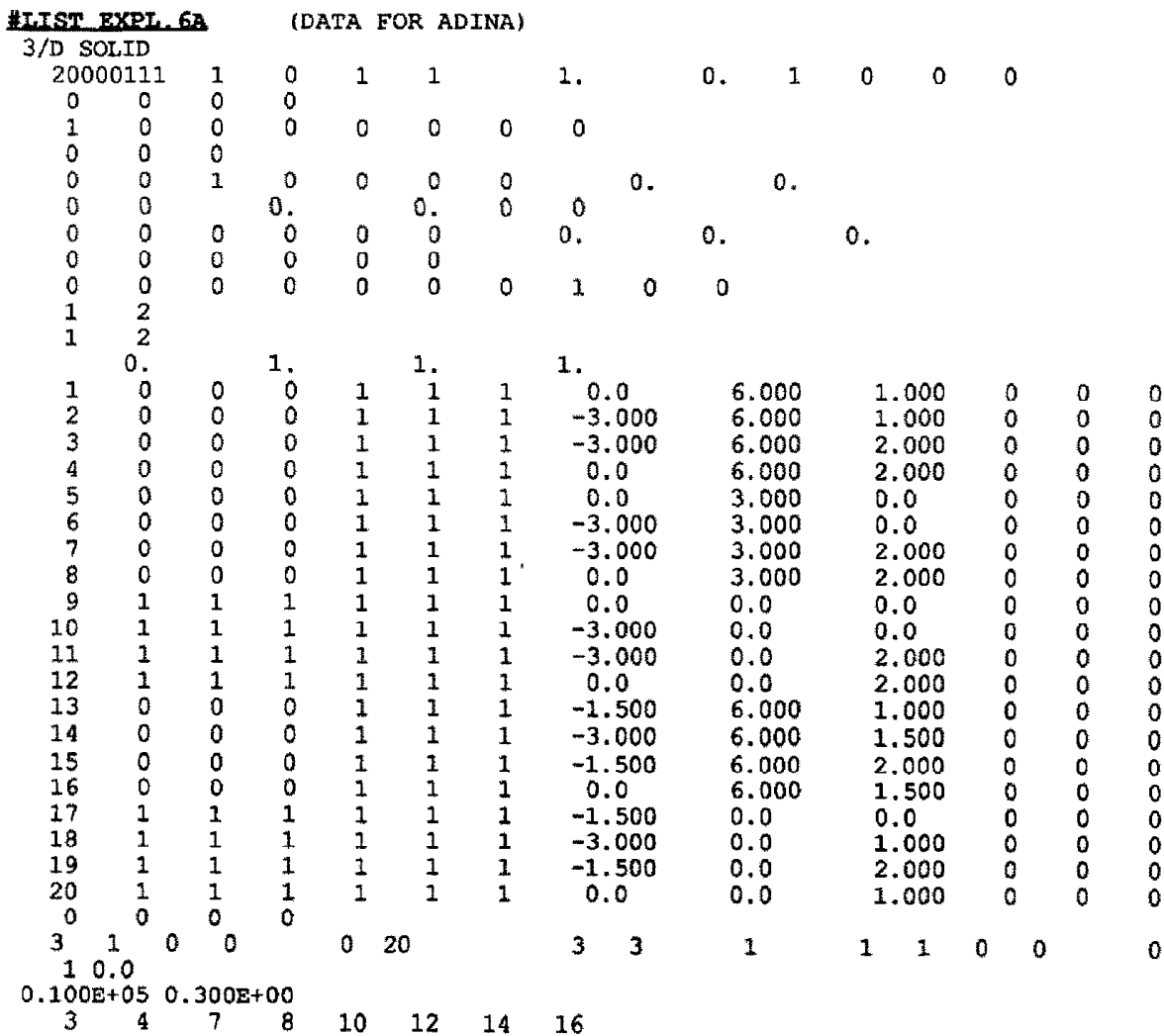




$\begin{array}{rrrrrrrrrrrr}1 & 20 & 20 & 1 & 1 & 0 & 0 & 0 & & 0 . & 0 & \\ 4 & 3 & 11 & 12 & 1 & 2 & 10 & 9 & & & & \\ 15 & 7 & 19 & 8 & 13 & 6 & 17 & 5 & 16 & 14 & 18 & 20 \\ 4 & 3 & 1 & -8.000 & & 0 . & 0 & & & & \end{array}$

EXAMPLE 6A

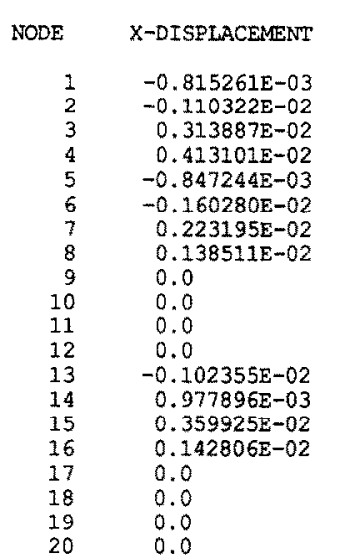

$3 \rightarrow$ SOLID IEXPL, 6 SOIVED WITH ADINAL

DISPLACEMENTS

$\begin{array}{ccc}\text { Y-DISPLACEMENT } & \text { Z-DISPLACEMENT } & \text { X-ROTATION } \\ -0.568847 \mathrm{E}-03 & -0.301279 \mathrm{E}-01 & \\ -0.585713 \mathrm{E}-03 & 0.173985 \mathrm{E}-01 & 0.0 \\ 0.493439 \mathrm{E}-02 & -0.172596 \mathrm{E}-01 & 0.0 \\ 0.741231 \mathrm{E}-02 & -0.314425 \mathrm{E}-01 & 0.0 \\ -0.402017 \mathrm{E}-02 & -0.942524 \mathrm{E}-02 & 0.0 \\ -0.291563 \mathrm{E}-02 & -0.486425 \mathrm{E}-02 & 0.0 \\ 0.345010 \mathrm{E}-02 & -0.502602 \mathrm{E}-02 & 0.0 \\ 0.438329 \mathrm{E}-02 & -0.963579 \mathrm{E}-02 & 0.0 \\ 0.0 & 0.0 & 0.0 \\ 0.0 & 0.0 & 0.0 \\ 0.0 & 0.0 & 0.0 \\ 0.0 & 0.0 & 0.0 \\ -0.561315 \mathrm{E}-03 & -0.240650 \mathrm{E}-01 & 0.0 \\ 0.209739 \mathrm{E}-02 & -0.172393 \mathrm{E}-01 & 0.0 \\ 0.636292 \mathrm{E}-02 & -0.241545 \mathrm{E}-01 & 0.0 \\ 0.319675 \mathrm{E}-02 & -0.305497 \mathrm{E}-01 & 0.0 \\ 0.0 & 0.0 & 0.0 \\ 0.0 & 0.0 & 0.0 \\ 0.0 & 0.0 & 0.0 \\ 0.0 & 0.0 & 0.0\end{array}$

STRESS CALCULATIONS FOR EIEMENT GROUR I (3/D CONTINUMM)

$\begin{array}{rrrrrrr}\begin{array}{r}\text { ELEMENT } \\ \text { NUMBER }\end{array} & \begin{array}{r}\text { OUTPUT } \\ \text { LOCATION }\end{array} & \text { STRESSXX } & \text { STFESSYY } & \text { STRESSZZ } & \text { STRESSXY } & \text { STRESSXZ } \\ & & & & & & \\ \text { STRESSYZ }\end{array}$

Total computation time comparison (CPU, sec) for 3D Bracket (Mult.-Node): MSAP, 0.25; NASTRAN, 4.49; ADINA, 0.18 .

\section{REFERENCES}

1. M. J. Kaldjian, Interactive data preprocessor program for Michigan SAP (MSAP). Comput. Struct. 6 (4/5), 405-412 (1976).

2. M. J. Kaldjian, PREMSAP and MSAPLOT Manual. NAME Report No. 236, University of Michigan, Ann Arbor, MI (1981).

3. M. J. Kaldjian, MSAP/SAP IV MSC/NASTRAN ADINA, interactive and comparative training programs. Course pack. Department of Naval Architecture and Marine Engineering, University of Michigan, Ann Arbor, MI (1988).

4. W. I. Anderson, MSC/NASTRAN Interactive Training Programs. John Wiley, New York (1983).

5. K. J. Bathe, E. L. Wilson and F. E. Peterson, SAP IV-a structural analysis program. University of California, Berkeley, CA (1974).

6. H. G. Schaeffer, MSC/NASTRAN static and normal modes analysis (1979).

7. K. J. Bathe, ADINA-a finite element program for automatic dynamic incremental nonlinear analysis. Report AE 79, ADINA Engineering, Watertown, MA (1970).

8. M. J. Kaldjian, Three dimensional interactive graphic display program for Michigan SAP (MSAP). Comput. Struct. 7 (2), 183-187 (1977).

\section{APPENDIX}

How to run the following programs, PREMSAP, MSAP and MSAPLOT, also PNASTRAN/ NASTRAN and PADINA/ADINA on the University of Michigan Terminal System (MTS).

\section{MSAP}

To prepare finite element data interactively:

1. \$RUN CENA:PREMSAP (and obtain input datafile, call it MDATA)

To obtain displacements and stresses (forces):

2. \$RUN CENA:MSAP $5=$ MDATA $6=-$ RESULT

3. STRUNCATE -DEF (the deflection file-DEF is created by MSAP)

\section{4. \$RENAME -DEF MDATAD}

To print out input data and results:

5. \$CONTROL ${ }^{*}$ PRINT $*$ PRINTER $=$ LINE ROUTE $=$ CNTR COPIES $=2$

6. SLIST MDATA *PRINT*

7. \$COPY -RESULT *PRINT* 
MSAPLOT

To obtain computer plots:

8. \$RUN CENA:MSAPLOT (on TEKTRONIX or Macintosh terminals) (You would need datafile MDATA, and deflection file MDATAD, and must follow the interactive instructions and menu list)

NASTRAN

To prepare finite element data interactively:

9. \$RUN CENA:PNASTRAN (and obtain input datafile, call it NDATA)
To obtain displacements and stresses (forces):

10. \$RUN NAST:NASTRAN SCARDS = NDATA SPRINT $=$ RESULT

ADINA

To prepare finite element data interactively:

11. SRUN CENA:PADINA (and obtain input datafile, call it ADATA)

To obtain displacements and stresses (forces):

12. $\$ R U N$ CENA:ADINA SCARDS $=$ ADATA SPRINT $=$ RESULT 